Article received on $16^{\text {th }}$ February 2012

Article accepted on $27^{\text {th }}$ February 2012

UDC: 78:004.738.5

\author{
Mirjana Veselinović-Hofman* \\ University of Arts in Belgrade \\ Faculty of Music \\ Department of Musicology
}

\title{
MUSIC AT THE PERIPHERY UNDER CONDITIONS OF DEGRADED HIERARCHY BETWEEN THE CENTRE AND THE MARGINS IN THE SPACE OF THE INTERNET**
}

\begin{abstract}
This paper deals with the emergence of a new kind of music of the centre and music of the margins, by means of the deconstruction of the 'old', historically and professionally founded and economically-politically enabled establishment of a hierarchical relation between the centre and the margins in the world of music. This deconstruction is here interpreted as a phenomenon initiated by the actions of the music industry, and is an immediate result of the expansion of the Internet, its meta-media and market logic. The newly emergent type of seniority between the central and the peripheral is perceived as currently highly important for the affirmation of peripheral musical cultures and their overcoming the status of marginal. Because their belonging to the new type of centre mostly depends literally on themselves and their relevant initiatives, without the psychological,
\end{abstract}

* Author contact information: mvesel@eunet.rs

** This study is realized within the science project Identiteti srpske muzike u svetskom kulturnom kontekstu [Identities of Serbian Music in the World Cultural Context] of the Department of Musicology of the Faculty of Music in Belgrade, supported by the Ministry of Education and Science, under the reg. no. 177019. 
socio-economical or political burden which is otherwise implied by the implanted awareness of belonging both to the marginal and the mainstream cultures within the 'old' hierarchy.

Keywords: centre, periphery, hierarchy, music industry, deconstruction, Internet

Апстракт: У овом раду реч је о формирању нове врсте музике центра и музике периферије, путем деконструисања „старог”, историјски професионално утемељеног а економско-политички омогућеног установљења хијерархијског односа између центра и периферије у свету музике. Та се деконструкција овде тумачи као појава која је иницирана деловањем музичке индустрије, а непосредни је резултат експанзије интернета, његове метамедијске и тржишне логике. Новонастали тип старешинства између централног и периферног, сагледава се као данас посебно значајан за афирмацију периферних музичких култура и њихово превазилажење статуса маргиналних. Јер њихова припадност центру новог типа понајвише зависи управо од њих самих и њихових осмишљених иницијатива, без оптерећености психолошким, друштвено-економским или политичким баластом који, иначе, носи са собом усађена свест и о припадности маргиналној и о припадности главној култури у оквиру „старе” хијерархије.

Кључне речи: центар, периферија, хијерархија, музичка индустрија, деконструкција, интернет

The phrase music on the periphery has a double meaning. It refers to the issues of the physiognomy of the music emerging in fringe cultures, to the issues of its artistic reputation in the world, but also to the music emerging on the fringe of the music itself, regardless of which cultures it belongs to, be they mainstream or fringe - i.e. in the sense of the phrase periphery in music. However, this latter phrase also potentially covers several things. It can refer to some aesthetically peripheral tendency within a musical culture, one which is not among its main creative currents, as well as to one which transcends the competence exclusively of the musical media. But it can also assume an extremely negative designation, when it refers to music which does not meet certain professional, vocational criteria, i.e. is not realized at a fitting level of quality. This paper, however, will be dealing only with the meaning that was mentioned first, i.e. with the music that emerges in the periphery of the leading musical cultures.

In this regard, it must be stressed right away that the phenomenon of periphery is here understood as a relational one, given that it is defined in relation to the phenomenon of centre. Periphery is the universal space located outside the centre, as a margin of its 'text', as something subordinate to it, but for that very reason something that essentially complements it. Because without the periphery, the centre as such would not even exist. Analogously, the notion of music in the periphery 
is here understood in relation to the notion of music in the centre, since the former concept as such is defined exactly in relation to the latter: as music which does not emerge in the domain of the centre, but at various distances from it - geographic, socio-economic, ideological, aesthetical, educational, professional and many more.

The very process of forming the centre, the meaning and ways of its operation, its viability as a centre, are complex in nature. It would be probably best to demonstrate it on the example of European music, dominated during its history and in the entire geographical space by the musical cultures of the West European countries as its centres, whereas these musical focal points took turns in that domination. ${ }^{1}$ Their rise to the status of centres was mostly caused by professional reasons, since those musical cultures were the points of origin and development of the elementary components of contemporary music institutions, e.g. the universally accepted notation system, musical instruments, performing ensembles, means of musical expression, compositional technique, building of musical forms, principles of orchestration, organization of musical institutions etc. Countries in other geographic areas - including ours - on the other hand, built their professionalism under the influence of these achievements by overcoming their compositional, and generally musical, amateurism through mastering that knowledge which the West acquired during the historical development of music and promoted into the vocational standard and content of musical education. In that respect, the West was reputed as the multiple musical authority and centre almost since the beginning of the history of professional European music, and all that was not part of its musical building site, that did not directly belong to that building site in the geographical, chronological, political, organizational, educational or criterial sense - in other words, everything whose quality was measured by the extent of accepting the knowledge and criteria of West European music - filled the 'white space' of its margins.

All the more so since, even today, the (sub)conscious of that centre contains some psychological reminder of its professional-historical value, which always justified the centre's conviction that such an advantage gained it the natural right to the status of arbitrator - in spite of the fact that the periphery often was musically more creative and innovative than the centre, ${ }^{2}$ that it was not its mere (sim-

\footnotetext{
${ }^{1}$ Let us just think of the history of domination of Italian, French and German opera, as well as, more narrowly, the domination of e.g. Italian opera centres in the $17^{\text {th }}$ century, such as Rome, Venice and Naples.

${ }^{2}$ Regarding that, let us mention Bartók's method of imaginary folklore, his treatment of string instruments or piano; unconventionality of Stravinsky's work with musical material, imaginativeness and innovativeness of his orchestral solutions; Janáček's speech melodies, Penderecki's and Lutosławski's aleatoric techniques, or Ligeti's micropolyphony, for example.
} 
plified) derivative. But in such situations, neither did the centre forget that the periphery actually displayed its creativity and innovativeness upon the centre's professional musical foundation, its results or at least certain starting points and incentives, as its ontological premise. And that was - and in the psychological sense it still largely is - enough for the periphery to remain the periphery 'forever', even when it essentially enriched the musical centre or, in fact, grew into its fresher and more innovative alternative. This was the case with the works of Bartók, Stravinsky, Penderecki, Lutosławski or Ligeti, for example. Admittedly, their works did become the acknowledged part of the music of the European centre (some of those composers, after all, spent part of their lives in the centre area), and their 'native' musical soil - thanks to their individual affirmation, as well as the organizational structure in all the segments of their musical cultures - did become known in the musical context of the centre and become integrated into it. However, those cultures as such, in that 'central', West European reception generally, nevertheless remained subordinate hierarchical members.

Of course, the causes of all that are not only professional. The relations between the centre and the periphery were always conclusively conditioned and regulated by the forms and arrangement of economic systems, as well as by the sheer force of capital, the concentration of which historically first occurred in Western Europe. Hence, that region had the material prerequisites for its ramified and rich spiritual development, so its centres, which were economically and politically strong, could become musically strong as well, and survive as such.

After the emergence of the Postmodern as the mega-culture of the $20^{\text {th }}$ century, such a global picture of the location of musical centres changed somewhat, ever since the establishment of the dominant economic, political and military role of the United States of America in the world after the Second World War. As today's strongest political factor, which under cover of its concept of 'spreading democracy' deftly and aggressively manipulates the life of its periphery -i.e. all the other parts of the world! - not only in the domain of politics and the economy but in culture, as well, the USA take a new attitude towards the music in the periphery. It differs from the attitude of the West European centres mostly by its treatment of what is specific for the music of particular peripheries. Namely, while the West European centres perceived that music in the sense of inspirational exoticism, whose authenticity they did not try to disturb or equalize but, at worst, disregarded or undervalued, acknowledging those margins all but parenthetically and superficially, ${ }^{3}$ the USA as the growing power centre strives to subject that au-

\footnotetext{
${ }^{3}$ In her paper 'General Histories of Music and the Place of the European Periphery' (Muzikologija/Musicology, 1, 2001, 141-149), Melita Milin considers the issue of disregarding the periphery on the case of presence of peripheral music mainly in the items of West
} 
thenticity to the globalization of their cultural 'model' which stems from the logic and practice of industrial production. Its interest, therefore, is to obtain the largest possible profit with the least possible amount of capital investment. As for the music, we are talking about the music industry.

Intending to secure a market for its products, the music industry - much the same as industries of all other products, e.g. consumer electronics and appliances, films, food or fashion - imposes a certain uniformity. Its most powerful agents are the media of mass communication and the Internet, 'its' social, commercial, entertaining and many other networks which most readily - in fact, from the inside - influence the changes in the habits and needs of the people, in the vital criteria generally, and thus in the context of the artistic, musical life, i.e. in the profile and purpose of creative work in such a life.

Therefore, musical culture, which by design stands apart from that industry, is exposed to a tidal wave of 'musical hamburgers', a uniformity whose long-term goal is to subdue the centres of musical life to the centre of musical industry. This is aimed not only at the world of music of the West European centres, but also at the peripheral centres, or even primarily at them.

During the implementation of that industrial concept of a centre, the periphery gradually changes its status, because eventually it enters the domain of the centre and becomes its structural part. In that respect, the initial hierarchical position of the periphery loses its distinctiveness and obviousness, and so the periphery with 'industrial ease' changes its status from subordinate towards foremost.

European historians of music. The author finds that ' $[\mathrm{n}]$ ational movements which led to the creation of national states in Europe provoked a climate of open contest between different peoples in all areas, including [...] the writing of histories of music', and consequently, 'national schools from peripheric parts of Europe (eastern Europe, Scandinavia, Spain) came to be regarded by music historians from the "Centre" as of minor value, mainly on the grounds that they introduced native folk music into highly organised art forms of Western music, and this threatened [...] the dignity and the universal character of Western music.' (Ibid., 141-142). She opines that the increase of this partiality or, more precisely, the display of the feeling of superiority over what was peripheral, was most pronounced in the Nazistic Germany and the Fascistic Italy; that the situation improved in the second half of the $20^{\text {th }}$ century; but that, nevertheless, subjective historiographical and musicological approaches to the periphery still exist. (Cf. ibid., 142) The author critically argues such claims using a certain number of historiographic publications and texts by West European authors as an example. She also mentions that some musicologists from the East European musical cultures, regarding their own musical region as more important than others in the same periphery, can resort to e.g. omitting certain peripheral regions from their musical history selections or giving undeservedly little space to some of their leading authors, but thus their attitude towards these musical environments becomes a mere copy of the attitude expressed towards them and, after all, these environments by the West European centres. 
But, as we shall see, that hierarchical turnaround, enabled and encouraged by the activity of the musical industry centre, can help the periphery at the same time, precisely by the affirmation of what constitutes its otherness. Because the periphery can embrace uniformity in one part of its musical culture, it can join it and become part of it, and yet enter that process with the full awareness of its own identity. And then - in some moment of its position, strengthened by profit and product marketing, in the sphere of that centre of uniformity - introduce elements of its own exclusivity into its content. But also, according to its own experiences with the functioning of the mechanism of the musical industry, affirm them outside that industry.

All this, at the same time, means that those uniform contents, during their expansion, necessarily undergo a change of their inner nature of the central, given that they will potentially include in their components that which is hierarchically subordinate. Hence, the peripheral tissue is implanted into its opposite: into the foremost, the uniform, the industrialized. And that new morphology of the central, conditioned and established by the musical industry, i.e. the morphology of its uniformity which is, incidentally, built and imposed primarily through the global network, can also absorb what is peripheral into it. Thus, eventually, at the level of such a levelled hierarchy, peripheral musical cultures are, in fact, indirectly offered both a method and a medium of affirmation of their authenticity outside the musical industry.

And, perhaps paradoxically, the electronic media by which the music industry and the uniformity it advocates are spread, are at the same time the media which potentially protect individual musical identities.

For example, after gaining experience with the importance of being present in the world's electronic communication, many fringe cultures, regardless of their being more or less integrated into the musical industry, become participants in various world projects related to the preservation of individual musical traditions - both professional and folklore, as well as contemporary achievements. Today, such projects are mostly focused on the multimedia storage of all the musical 'goods' of individual traditions, thus ensuring their accessibility at the global level, as well as the local materials which, by their active presence in the world cultural exchange, actually build its global character. ${ }^{4}$ In that respect, music of all cultures - not only the peripheral ones - will find great significance in the already widespread realization of the project of establishing mutually compatible electronic musical libraries and multimedia archives all over the world, ${ }^{5}$ which make the ex-

\footnotetext{
${ }^{4}$ For more on this subject cf. Mirjana Veselinović-Hofman, 'Multimedia Archives as a Step Towards World Music', New Sound, 24, II/2004, www.newsound.org.rs / 'Мултимедијски архиви као корак ка светској музици', Нови звук, 24, II/2004, 23-31.

${ }^{5}$ Cf. ibid.
} 
istence and operation 'of a general, reliable and easily accessible source of information on music heritage worldwide' possible. ${ }^{6}$ Thus, the participating of musical environments in these projects - both the mainstream and the marginal ones today is almost crucial for the affirmation of their musical identities, since these projects, as well as numerous, diversely organized and networked web-sites, enable the existence, in an open and directly accessible form, of their worlds of music in many forms of their content: as recordings of compositions of all kinds of music, as scores, as texts on music in journals and collections, as monographs, as books of an encyclopaedic nature...

Thus, the process of global musical uniformization through modern means of communication is equally directed to levelling the qualities of the periphery, above all within the musical industry, and to its preservation and affirmation outside that industry. ${ }^{7}$

Therefore, it can be said that the current system of information and communication networks is actually forming another, parallel, new centre, arising from the equated importance of the main and the subordinate centres. This new centre is not a part of the musical industry as the centre of cultural, musical globalization, but it is formed in the sphere of positive experiences with the marketing logic and practice of that industry, whose prerequisite is governing the public communication space. In other words, the nature of that new centre is primarily of the media; hence it exists above those 'old' centres and above their peripheries to the effect that, in the media sense, it treats them equally as its constructive and content-related potential: 'old' centres and 'old' peripheries become equal before the media. Therefore, the contents included in computer networks and appropriate web-sites become a part of the centre, and all those not represented there remain on its periphery.

It is thus understandable why more and more musical environments, which stand apart from the machinery of the musical industry, deliberately join the appropriate projects and web-sites: because it ensures worldwide product marketing and the affirmation of their identity. This is particularly significant for contemporary music creation, not only for composers but also for performers, musicologists and theoreticians, given that, in general, the sphere of music, even contemporary music, can be represented in the Internet communication by all of its segments in turn, and each of these segments can be placed in the world 'shop front'. They can be represented by various kinds of information - often very comprehensive, on styles, authors and works, as well as by acoustic presentations of the works,

\footnotetext{
${ }^{6}$ Ibid., 23.

${ }^{7}$ Cf. ibid.
} 
frequently accompanied by their written forms which 'move' on screen in real time, by texts which can be 'leafed through' on screen etc. Creativity is thus affirmed, propagated, made accessible, even exposed to public scrutiny, ${ }^{8}$ regardless of whether its 'original' cultural musical location is/was central, i.e. West European, or peripheral. In other words, in spite of being (expectedly) present in the informative and critical columns of reputable printed media, in spite of being present on radio and television - today the absence from the Internet communication can even 'make' the results of a leading musical culture peripheral on the Internet. And vice versa: if a certain musical 'location' is/was peripheral 'by origin', it ceases to be a priori peripheral in the central space of electronic networking.

The 'ideality' of this picture, however, can easily be disputed by pointing out that, for example, one musical work which circulates intensely on these electronic communication trajectories is not necessarily one that is artistically representative. Namely, such exposure of the work on the global network may be the result of the author's exclusive personal decision about which of the works will be put up on the appropriate web-site, instead of some institutional, professional selection. If, however, we refer to the institutional projects of musical environments themselves to join that electronic communication, the danger of negative selection is diminished, because such projects generally include the professional, musicological, critical choice of the content which will represent a musical environment. That is, which works and which basic values will feature in the global communication spaces as exponents of the identity of the musical culture in question. Of course, in principle, no selection is necessarily and completely the 'right' one, authoritative in the absolute sense. Neither are, after all, the selections made at world music festivals still considered to be extremely important - in fact, in the domain of real, non-electronic musical life even the most important! - places for the world professional promotion of composers and their particular works. By that promotional function, festivals in a specific way could even be compared with the Internet centre. Because some, which are e.g. just reviews of the creative results achieved in a certain period of time, are similar to individually created web-sites by their multilateral diversity; and other festivals, i.e. the majority, which have thematic profiles and are based upon a certain selection, can be associated with institutionally, 'programmatically' conceived web-sites. However, by the nature of things, compared to the 'network' of festivals, the global network covers the world music space in the literal sense. Under certain technological conditions, it can reach every corner of the planet; it is much more complete, more operational

\footnotetext{
${ }^{8}$ Such as the one available at e.g. YouTube, which defines the rating of a composition or its performance by the number of stars or free comments by the visitors.
} 
and more assertive than world festivals and the accessibility they provide for 'their' music.

Of course, the affirmation of a musical culture in the electronic space of world music exchange is strongly influenced by the quality of all the represented components of that culture, and ways of achieving that representation, but they are not crucial for the existence of that culture on the Internet as the new media centre, in fact the centre of meta-media connections of world music. Because the purpose of that centre is primarily in the storage and circulation of as much content as possible, i.e. the open supply and competition in an entire, continually active, ever richer and busier market of music of the whole world.

In such circumstances, it appears that for a musical culture and all of its individual constituents, a culture which strives to overcome its peripheral status, the road to accomplishing that is much clearer than in the circumstances of the "conventional' hierarchy between the centre and the periphery, which both members of that opposition, the main and the subordinate alike, are essentially aware of. The Internet space as a centre, however, does not carry that psychological burden, although the data on the attachment of a certain musical work either to a particular West European, central musical domain, or to a peripheral one, are not hidden in that space. However, that 'genetic' attachment to the one or the other is not crucial for the public evaluation of the work. What is crucial is to make the work accessible to that public, i.e. to make it a part of the electronic network as the new centre. By that logic, none of what exists on the electronic network is peripheral in the former sense of the word. On the contrary, peripheral is only what is located outside that network. And the possible dynamic of rating of the works and the 'strong demand' for them on the market of some web-sites within that network, which admittedly could be understood as a kind of variable, 'fluctuating', 'shifting' periphery within the Internet space itself, essentially just degrades the 'old' status of the central and the marginal.

Meanwhile, we should not lose sight of the fact that the data and links which search engines refer to are nevertheless given in a certain order: among, say, 220,000 results of a search related to a particular musical term, some of them are opened first, or at least are placed on the first 10 pages of the results, in spite of the fact that many of them can even be found again on various other pages. It is also distinctive that, for example, under a certain musical phenomenon one is looking for, the first result which can be opened leads to a professionally unconvincing reference to that phenomenon. Of course, this is always the consequence of the search engine's organizational logic, which depends on the administrator of the particular provider and the procedure used for receiving and classifying data, a procedure which probably also involves financial gain. At any rate, the organiza- 
tion of search results, in principle, is not based upon the professional valorisation of the gathered material or its expert ranking. Thus, it is reasonable to assume that the provider organizes the first few pages of the search offered, as a certain 'shop front' with those 'publications' which can make that shop front attractive, i.e. most profitable. From that perspective, it can be said that the data in the first few pages of search results are maybe 'more communicative' than the others, which still does not mean that these other data are peripheral. Not only, as we said, because the data are repeated in different places in the results lists, making those places and those data ultimately equal to all the other places and data, but most of all because the search can be started in any order, and thus the first few results can become the last ones. That depends on the users who are searching, and who in fact personally determine what is important or subordinate to them, and thus necessarily what in the moment of their search 'becomes' the main or subordinate content on the network, i.e. on the web-site which is, for the users, central at that moment.

The new nature of both the periphery and the centre advocated by the Internet gives an opportunity to the peripheral musical cultures to acquire a socially fairer and psychologically less burdened position on the Internet, compared to the one they hold in the conditions of the long-ago established, 'old' hierarchy between the central and the marginal. But that 'old' hierarchy has not disappeared, of course, and is still, outside of the Internet, based upon the historic power of professionalism and the economical-political position of a musical culture in the world. Therefore, even if e.g. certain musical achievements from a peripheral culture enjoyed the leading rating on the Internet, it does not mean their hierarchical position outside of the Internet would automatically change. The Internet only enabled a new form of existence in general, and thus the existence of cultural and musical identities - peripheral and central, in the sense of their 'telepresence'. Therefore, it is not possible that musical achievements automatically transfer their position from the space of the Internet hierarchy to the space of the 'old' hierarchy of musical reality outside of the Internet, without their real presence in all the aspects of professional musical life at the level of world relations and the mechanism of professional affirmation which operates within the institution of music outside of the Internet. And which is, as the basic prerequisite, backed up by an economically strong state.

Although the 'old' hierarchy between the centre and the periphery is deeply rooted and present in the world of music, the deconstruction of their opposing members, encouraged by the musical industry and occurring in the space of the Internet, has resulted in a new type of seniority between the central and the peripheral, as well as in a significantly different alternative in the sense of the media, logic and principles. This alternative, as we pointed out, today is particularly im- 
portant for the peripheral musical cultures, since the inclusion in the centre of the new type and the forms of being present in it mostly depend on those cultures and their relevant initiatives when creating all of their web-sites.

Translated by Goran Kapetanović

\section{REFERENCES}

Frith, Simon, 'Music and Identity', in: Stuart Hall and Paul du Gay (eds.). Questions of Cultural Identity, Los Angeles - London, etc.: Sage, 1996 (repr. 2011), 108-127.

Hall, Stuart and Paul du Gay (eds.), Questions of Cultural Identity, Los Angeles - London, etc.: Sage, 1996 (repr. 2011)

Milin, Melita, 'General Histories of Music and the Place of the European Periphery', Музикологија/Musicology, 1, 2001, 141-149.

Ricoeur, Paul, Oneself as Another (Soi-même comme un autre), transl. by Kathleen Blamey, Chicago: University of Chicago Press, 1995.

Tempelman, Sasja, 'Constructions of Cultural Identity: Multiculturalism and Exclusion', Political Studies, XLVII, 1999, 17-31.

Veselinović-Hofman, Mirjana, 'Multimedia Archives as a Step Towards World Music', New Sound, 24, II/2004, 23-31. 